D.M. Akhmanova ${ }^{1}$, M.I. Ramazanov ${ }^{1-3}$, M.G. Yergaliyev ${ }^{1,4}$

${ }^{1}$ Ye.A. Buketov Karaganda State University, Kazakhstan;

${ }^{2}$ Institute of Mathematics and Mathematical Modeling CS MES RK, Almaty, Kazakhstan;

${ }^{3}$ Institute of Applied Mathematics, Karaganda, Kazakhstan;

${ }^{4}$ Al-Farabi Kazakh Ntional University, Almaty, Kazakhstan

(E-mail: danna.67@mail.ru)

\title{
On an integral equation of the problem of heat conduction with domain boundary moving by law of $t=x^{2}$
}

\begin{abstract}
In the article it is shown that the homogeneous Volterra integral equation of the second kind, to which the homogeneous boundary value problem of heat conduction in the degenerating domain is reduced, has a nonzero solution. The boundary of the domain moves with a variable velocity. It is shown that the norm of the integral operator acting in classes of continuous functions is equal to 1. Mellin transformation is applied to the obtained integral equation. It is proved that for certain values of the spectral parameter the eigenvalues of the integral equation will be simple.
\end{abstract}

Keywords: heat conduction, boundary value problems, a kernel, Mellin transformation, convolution theorem, eigenfunction.

In general cases, the methods of separation of variables and integral transformations are not applicable to problems in domains that are degenerated to the point, since for this type of problems methods of separating the variables and integral transformations can not be applied, as remaining within the classical methods of mathematical physics you cannot conform the solution of the heat equation to the boundary of domain. Therefore the question about the study of boundary value problems with degenerating the domain at the initial moment of time is actual. Using the method of heat potentials solving such problems is reduced to the study of singular Volterra integral equations of the second kind. Feature of these equations consists in incompressibility of the kernel and is expressed in the fact that the homogeneous equation has nonzero solutions and corresponding non-homogeneous equation can not be solved by classical methods.

\section{Statement of the problem}

We consider the first boundary value problem of heat conduction in the degenerating domain (domain with a moving boundary; the boundary of the domain is moving with variable speed). In the domain $G=\{(x ; t): t>0,0<x<\sqrt{t}\}$ to find a solution to the heat equation

$$
\frac{\partial u}{\partial t}=a^{2} \frac{\partial^{2} u}{\partial x^{2}}
$$

satisfying the boundary conditions:

$$
\left.u(x, t)\right|_{x=0}=0,\left.\quad u(x, t)\right|_{x=\sqrt{t}}=0 .
$$

Such problems in the domain $Q=\{(x ; t): \quad t>0, \quad 0<x<t\}$ are investigated in works [1-3].

\section{Reducing the problem to an integral equation}

We are looking for a solution to boundary problem (1)-(2) as the sum of the heat potentials of the double layer [4]

$$
\begin{gathered}
u(x, t)=\frac{1}{4 a^{3} \sqrt{\pi}} \int_{0}^{t} \frac{x}{(t-\tau)^{\frac{3}{2}}} \exp \left\{-\frac{x^{2}}{4 a^{2}(t-\tau)}\right\} \nu(\tau) d \tau+ \\
+\frac{1}{4 a^{3} \sqrt{\pi}} \int_{0}^{t} \frac{x-\sqrt{\tau}}{(t-\tau)^{\frac{3}{2}}} \exp \left\{-\frac{(x-\sqrt{\tau})^{2}}{4 a^{2}(t-\tau)}\right\} \psi(\tau) d \tau .
\end{gathered}
$$


It is known that function (3) satisfies equation (1) for any $\nu(t)$ and $\psi(t)$ [4; 476-480]. Using conditions (2) and the properties of the heat potential, we obtain the integral equation:

$$
\psi(t)-\int_{0}^{t} k(t, \tau) \psi(\tau) d \tau=0,
$$

where

$$
\begin{aligned}
k(t, \tau)= & \frac{1}{2 a \sqrt{\pi}}\left\{\frac{\sqrt{t}+\sqrt{\tau}}{(t-\tau)^{3 / 2}} \exp \left(-\frac{(\sqrt{t}+\sqrt{\tau})^{2}}{4 a^{2}(t-\tau)}\right)+\right. \\
& \left.+\frac{\sqrt{t}-\sqrt{\tau}}{(t-\tau)^{3 / 2}} \exp \left(-\frac{(\sqrt{t}-\sqrt{\tau})^{2}}{4 a^{2}(t-\tau)}\right)\right\} .
\end{aligned}
$$

In equation (4) we introduce a new function

$$
\varphi(t)=\sqrt{t} \psi(t) \in M\left(R_{+}\right), \text {where } M\left(R_{+}\right)=L_{\infty}\left(R_{+}\right) \bigcap C\left(R_{+}\right) ;
$$

and consider integral equation (4) with a real parameter $\lambda$

$$
\varphi(t)-\lambda \int_{0}^{t} K(t, \tau) \varphi(\tau)=0,
$$

where

$$
K(t, \tau)=\sqrt{t / \tau} k(t, \tau)
$$

The kernel $K(t, \tau)$ has the following properties

1) $K(t, \tau) \geq 0$ and is continuous on $0<\tau \leq t$;

2) $\lim _{t \rightarrow t_{0}} \int_{t_{0}}^{t} K(t, \tau) d \tau=0$

3) $\int_{0}^{t} K(t, \tau) d \tau=1$

The properties 1) and 2) are obvious. Let us prove the validity of property 3 ).

$$
\begin{gathered}
\frac{1}{2 a \sqrt{\pi}} \int_{0}^{t} \sqrt{\frac{t}{\tau}} k(t, \tau) d \tau=\left|\tau:=t \cdot\left(\frac{1-z^{2}}{1+z^{2}}\right)^{2}\right|= \\
=\frac{1}{a \sqrt{\pi}}\left[\int_{0}^{1} \exp \left\{-\frac{1}{4 a^{2} z^{2}}\right\} \frac{d z}{z^{2}}+\int_{0}^{1} \exp \left\{-\frac{z^{2}}{4 a^{2}}\right\} d z\right]= \\
=\frac{1}{a \sqrt{\pi}}\left[\int_{1}^{\infty} \exp \left\{-\frac{z^{2}}{4 a^{2}}\right\} d z+\int_{0}^{1} \exp \left\{-\frac{z^{2}}{4 a^{2}}\right\} d z\right]= \\
=\frac{1}{a \sqrt{\pi}} \int_{0}^{\infty} \exp \left\{-\frac{z^{2}}{4 a^{2}}\right\} d z=1 .
\end{gathered}
$$

Remark. From this property we conclude that when $\lambda=1, \varphi(t)=C$ (where $C=$ const) is the solution to equation (6).

\section{Solving integral equation (6) by means of the Mellin transformation}

We rewrite equation (6) in the form

$$
\varphi(t)-\lambda \int_{0}^{t} \sqrt{\frac{t}{\tau}} k_{1}\left(\frac{t}{\tau}\right) \frac{\varphi(\tau)}{\tau} d \tau=0,
$$




$$
\begin{aligned}
k_{1}(\theta)= & \frac{1}{2 a \sqrt{\pi}}\left\{\frac{\sqrt{\theta}+1}{(\sqrt{\theta}-1)^{3 / 2}} \exp \left(-\frac{(\sqrt{\theta}+1)^{2}}{4 a^{2}(\theta-1)}\right)+\right. \\
& \left.+\frac{\sqrt{\theta}-1}{(\theta-1)^{3 / 2}} \exp \left(-\frac{(\sqrt{\theta}-1)^{2}}{4 a^{2}(\theta-1)}\right)\right\} .
\end{aligned}
$$

Introducing the function $K_{1}(\theta)$ according to the formula

$$
K_{1}\left(\frac{t}{\tau}\right)=\left\{\begin{array}{l}
k_{1}\left(\frac{t}{\tau}\right), 0<\tau<t<+\infty \\
0,0<t \leq \tau<+\infty
\end{array}\right.
$$

we rewrite the equation (7) in the form

$$
\varphi(t)-\int_{0}^{+\infty} \frac{\sqrt{t}}{\sqrt{\tau}} K_{1}\left(\frac{t}{\tau}\right) \frac{\varphi(\tau)}{\tau} d \tau=0
$$

Applying Mellin transformation to the last equation and taking into account the convolution theorem [5; 385]

$$
t^{\alpha} \cdot \int_{0}^{\infty} \tau^{\beta} \cdot f_{1}\left(\frac{t}{\tau}\right) \cdot f_{2}(\tau) d \tau \div \widehat{f}_{1}(s+\alpha) \cdot \widehat{f}_{2}(s+\alpha+\beta+1),
$$

we get

$$
\widehat{\varphi}(s) \cdot\left[1-\lambda \cdot \widehat{K}_{1}\left(s+\frac{1}{2}\right)\right]=0
$$

where

$$
\begin{gathered}
\widehat{K}_{1}\left(s+\frac{1}{2}\right)=\frac{1}{a \sqrt{\pi}} \int_{0}^{\infty}\left\{\frac{|1-z| \cdot(1+z)}{1+z^{2}}\right\}^{-2 s} \exp \left\{-\frac{z^{2}}{4 a^{2}}\right\} d z, \\
\widehat{\varphi}(s)=\int_{0}^{\infty} \varphi(t) \cdot t^{s-1} d t .
\end{gathered}
$$

It is known [5; 180-181], that form of the eigenfunctions of integral equation (8) is determined by the roots of the transcendental equation for the parameter $s$ :

$$
\lambda \cdot \widehat{K}_{1}\left(s+\frac{1}{2}\right)=1 .
$$

Eigenfunctions

$$
\varphi_{k}(t)=t^{s_{k}}
$$

correspond to the real (single) roots $s_{k}$.

Following [6], we denote by $\Lambda$ the set of positive numbers $\lambda$, and by $\Sigma$ the set of numbers $s<-\frac{1}{2}$. It is easily seen that equation (9) establishes a one-to-one correspondence between $\Lambda$ and $\Sigma$. This is obvious, since

$$
\begin{gathered}
\frac{d}{d s} \widehat{K}_{1}\left(s+\frac{1}{2}\right)= \\
=\frac{1}{a \sqrt{\pi}} \int_{0}^{\infty}\left\{\frac{\left|1-z^{2}\right|}{1+z^{2}}\right\}^{-2 s} \exp \left\{-\frac{z^{2}}{4 a^{2}}\right\} \ln \left|\frac{1+z^{2}}{1-z^{2}}\right| \geq 0,
\end{gathered}
$$




$$
\lim _{s \rightarrow+\frac{1}{2}} \widehat{K}_{1}\left(s+\frac{1}{2}\right)=+\infty, \lim _{s \rightarrow-\infty} \widehat{K}_{1}\left(s+\frac{1}{2}\right)=0 ; \widehat{K}_{1}\left(\frac{1}{2}\right)=1 .
$$

Also we denote by $C_{\gamma}\left(R_{+}\right)$Banach space of functions $\varphi(t) \in C\left(R_{+}\right)$, with finite norm

$$
\|\varphi\|_{\gamma}=\max \left|t^{\gamma} \varphi(t)\right|, \quad \gamma=\text { const. }
$$

The following theorem holds.

Theorem. For all $\lambda \in \Lambda$ there is a number $s$ such that the functions $\varphi(t)=C t^{s}$ (where $C=$ const) are eigenfunctions of equation (6) in the space $C_{-s}\left(R_{+}\right)$. In thies space $C_{-s}\left(R_{+}\right)$all eigenvalues of equation (6) are simple.

From the theorem and remark it follows that for $\lambda=1$ equation (6) has eigenfunction $\varphi(t)=C=$ const, and initial equation (4) has eigenfunction $\psi(t)=\frac{C}{\sqrt{t}}$.

Brief abstract of this work has been published in the Materials of the workshop «Differential operators and modeling of complex systems» (7-8, April, 2017, in Almaty, Kazakhstan) [7].

\title{
Acknowledgements
}

This study is supported by grants No. AP05130928, AP05132262.

\section{References}

1 Amangaliyeva M.M. On one homogeneous problem for the heat equation in an infinite angular domain / M.M. Amangaliyeva, M.T. Jenaliyev, M.T. Kosmakova, M.I. Ramazanov // Siberian Mathematical Journal. - 2015. - 56. - No. 6. - P. 982-995.

2 Amangaliyeva M.M. About Dirichlet boundary value problem for the heat equation in the infinite angular domain / M.M. Amangaliyeva, M.T. Jenaliyev, M.T. Kosmakova, M.I. Ramazanov // Boundary Value Problems. - 2014. - No. 213. - P. 1-21.

3 Kosmakova M.T. On an integral equation of the Dirichlet problem for the heat equation in the degenerating domain / M.T. Kosmakova // Bulletin of University of Karaganda. Series mathematics. - 2016. No. $1(81)$. - P. $62-67$.

4 Тихонов А.Н. Уравнения математической физики / А.Н. Тихонов, А.А. Самарский. - М.: Наука, 1977.

5 Полянин А.Д. Справочник по интегральным уравнениям / А.Д. Полянин, А.В. Манжиров. - М.: Физматлит, 2003.

6 Nakhushev A.M. Inverse problems for degenerating equations and Volterra integral equations of the third kind / A.M. Nakhushev // Differential Equations. - 1974. - Vol. 10. - No. 1. - P. 100, 101.

7 Akhmanova D.M. On an integral equation of the thermal problem when moving the boundary by law of $t=x^{2}$ / D.M. Akhmanova, M.I. Ramazanov, M.G. Yergaliyev // Kazakh Mathematical Journal. - 2017. - 17. - No. 1. - P. 54, 55 .

\section{Д.М. Ахманова, М.И. Рамазанов, М.Г. Ерғалиев}

\section{Шекарасы $\mathrm{t}=\mathrm{x}^{2}$ заңдылығы бойынша өзгеретін жылуөткізгіштік есебінің интегралдық теңдеуі туралы}

\begin{abstract}
Мақалада аймақта біртекті екінші ретті Вольтерра интегралдық теңдеуіне келтіретін жылуөткізгіштік біртекті есебінің нөлдік емес шешімінің бар екендігі көрсетілген. Аймақтың шекарасы айнымалы жылдамдықпен жылжиды. Үздіксіз функциялар кластарында әрекет ететін интегралдық оператордың нормасы бірге тең екені көрсетілген. Алынған интегралдық теңдеуге Меллин түрлендіруі қолданылды. Спектралды параметрдің анықталған мәндерінде интегралдық теңдеудің меншікті мәндері қарапайым болатыны дәлелденді.
\end{abstract}

Kiлm сөздер: жылуөткізгіштік теңдеуі, шеттік есептер, өзек, Меллин түрлендіруі, конволюция теоремасы, меншікті функция. 
Д.М. Ахманова, М.И. Рамазанов, М.Г. Ергалиев

\title{
Об одном интегральном уравнении задачи теплопроводности с границей, движущейся по закону $\mathrm{t}=\mathrm{x}^{2}$
}

\begin{abstract}
В статье показано, что однородное интегральное уравнение Вольтерра второго рода, к которому сведена однородная краевая задача теплопроводности в вырождающейся области, имеет ненулевое решение. Граница области движется с переменной скоростью. Показано, что норма интегрального оператора, действующего в классах непрерывных функций, равна $1 . \mathrm{K}$ полученному интегральному уравнению применяется преобразование Меллина. Доказано, что при определенных значениях спектрального параметра собственные значения интегрального уравнения будут простыми.
\end{abstract}

Ключевые слова: уравнение теплопроводности, краевые задачи, ядро, преобразование Меллина, теорема о свертке, собственная функция.

\section{References}

1 Amangaliyeva, M.M., Jenaliyev, M.T., Kosmakova, M.T., \& Ramazanov, M.I. (2015). On one homogeneous problem for the heat equation in an infinite angular domain. Siberian Mathematical Journal, 56, 6, 982-995.

2 Amangaliyeva, M.M., Jenaliyev, M.T., Kosmakova, M.T., \& Ramazanov, M.I. (2014). About Dirichlet boundary value problem for the heat equation in the infinite angular domain. Boundary Value Problems, No. 213, 1-21.

3 Kosmakova, M.T. (2016). On an integral equation of the Dirichlet problem for the heat equation in the degenerating domain. Bulletin of University of Karaganda. Series mathematics, No. 1(81), 62-67.

4 Tihonov, A.N., \& Samarskii, A.A. (1977). Uravneniia matematicheskoi fiziki [Equations of the mathematical physics]. Moscow: Nauka [in Russian].

5 Polyanin, A.D., \& Manzhirov, A.V. (2003). Spravochnik po intehralnym uravneniiam [Handbook of integral equations]. Moscow: Fizmatlit [in Russian].

6 Nakhushev, A.M. (1974). Inverse problems for degenerating equations and Volterra integral equations of the third kind. Differential Equations, Vol. 10, No. 1, 100, 101.

7 Akhmanova, D.M., Ramazanov, M.I., \& Yergaliyev, M.G. (2017). On an integral equation of the thermal problem when moving the boundary by law of $t=x^{2}$. Kazakh Mathematical Journal, 17, 1, 54, 55. 